\title{
HUBUNGAN ANTARA KEPUASAN NASABAH DENGAN POST PURCHASE BEHAVIOR STUDI EMPIRIS DI BSM DEPOK
}

\author{
CORRELATION BETWEEN CUSTOMER SATISFACTION WITH POST PURCHASE BEHAVIOUR: \\ EMPIRICAL STUDY IN BSM DEPOK
}

\section{Reny Fitriana Kaban *1}

*) Program Studi Ekonomi Syariah, Perbanas Institute Jl.Perbanas Karet Kuningan Setiabudi, Gedung Unit V lantai 2, Jakarta 12940

\begin{abstract}
This research aimed to analyze the relationship between customer satisfaction with postpurchase behavior for a marketing strategy development in Bank Syariah Mandiri (BSM) branch Depok. This research was conducted by interview using questionnaires to the customers who made a transaction in BSM branch Depok during the year time before this study. The obtained data on customer satisfaction and post-purchase behavior were formed on a Likert scale. The data were classified by cross-tabulation and analyzed by $\left(\chi^{2}\right)$ Chi-Square test. The results show that there was a correlation between customer satisfaction and post-purchase behavior on loyalty, in the forms of saying positive things about sharia bank to other people, recommending sharia bank to others, remaining loyal to sharia bank, and keep doing business with Syariah bank. Another post-purchase behavior that correlated with customer satisfaction was moving, such as switching to competitors due to better prices, and two external responses. such as negative statements to the other customers and complaining to external agencies. Although, in general, the customers' rate satisfies on service quality delivered by BSM branch Depok and agree to be loyal and pay more, it is strongly suggested that the bank keep maintaining and improving its service quality and respond to the complaints of unsatisfied customers. Increasing the speed of service, providing facilities to support customer convenience, and strengthening the brand or image of the bank are some things that need to be considered more seriously by bank management.
\end{abstract}

Keywords: customer satisfaction, post purchase behavior, service quality, chi square test, syariah bank

\begin{abstract}
Abstrak: Penelitian ini bertujuan mengetahui seberapa besar hubungan kepuasan nasabah dengan post purchase behavior sebagai dasar penetapan strategi pemasaran dan pengembangan Bank Syariah Mandiri (BSM) Kantor Cabang Depok. Data yang diperoleh berupa peringkat kepuasan nasabah dan post purchase behavior dibentuk dalam skala Likert. Data yang diperoleh selanjutnya diklasifikasikan dan dianalisis dengan uji Chi Square $\left(\chi^{2}\right)$ dan tabulasi silang. Hasil penelitian menujukkan ada kecenderungan hubungan yang cukup kuat antara kepuasan nasabah dengan post purchase behavior yang berbentuk loyalitas seperti membicarakan hal-hal positif kualitas pelayanan bank syariah kepada orang lain, merekomendasikan jasa bank syariah kepada orang lain, tetap loyal dengan bank syariah dan melakukan bisnis lebih banyak dengan bank syariah. Perilaku post purchase behavior lainnya yang memiliki hubungan cukup kuat dengan kepuasan nasabah yakni pindah dalam bentuk mengalihkan bisnis kepada kompetitor karena harga yang lebih baik dan dua bentuk respon eksternal, yakni mengeluh kepada nasabah lain dan mengeluh kepada pihak ketiga. Kendati secara umum nasabah telah menilai puas atas kualitas pelayanan yang diberikan BSM Kantor Cabang Depok dan menyatakan setuju untuk loyalitas dan bayar lebih, disarankan kepada pihak bank untuk terus meningkatkan kualitas pelayanannya serta memperhatikan keluhan nasabah yang merasa tidak puas. Meningkatkan kecepatan pelayanan, pengadaan fasilitas penunjang kenyamanan nasabah serta memperkuat brand atau citra bank adalah beberapa hal yang perlu diperhatikan lebih serius oleh manajemen bank.
\end{abstract}

Kata kunci: kepuasan nasabah, post purchase behavior, kualitas pelayanan, uji Chi Square, bank syariah

\footnotetext{
${ }^{1}$ Corresponding author:

Email: reny.fitriana@perbanas.id
} 


\section{PENDAHULUAN}

Bank Islam atau bank syariah telah tumbuh dalam hal ukuran dan jumlah yang cepat di seluruh dunia dalam dua dekade terakhir, hal ini sebagaimana yang dikemukakan oleh perusahaan riset The Asian Banker, bahwa aset 100 bank syariah top dunia di tahun 2011 mencapai US\$ 580 miliar. Aset ini meningkat 66\% dari US\$ 350 miliar pada 2007 (Amin, 2012). Untuk di Indonesia sendiri, pertumbuhan jumlah kantor individual perbankan Syariah hingga Juni 2018 berjumlah 2.467, jumlah ini meningkat lebih dari tiga kali lipat sejak tahun 2008. Hal ini dapat dilihat pada Tabel 1.

Tabel 1. Pertumbuhan jumlah kantor individual perbankan syariah

\begin{tabular}{lcc}
\hline Kelompok Bank & 2008 & 2018 \\
\hline Bank Umum Syariah & 581 & 1827 \\
Unit Usaha Syariah & 241 & 349 \\
BPRS Syariah & 185 & 291 \\
Total & 782 & 2467 \\
\hline
\end{tabular}

Sumber: OJK (2008 dan 2018)

Peningkatan kuantitas bank syariah berdampak pada pada intensitas kompetisi diantara para pelakunya, tidak hanya terhadap sesama bank syariah, tetapi juga dengan bank konvensional. Sangat esensial bagi bank syariah untuk meningkatkan kualitas pelayanannya dan menawarkan produk-produk inovatif agar dapat merespon peluang yang ada di era globalisasi saat ini, Oleh sebab itu, bank syariah harus mengembangkan suatu strategi pemasaran untuk mencapai keunggulan daya saing dan menciptakan posisi daya saing yang solid berbasis kualitas pelayanan (Ahmed et al. 2016).

Bank Syariah Mandiri (BSM) khususnya kantor cabang Depok, sebuah lembaga jasa keuangan dan perbankan, saat ini memiliki banyak pesaing dan dituntut untuk selalu menjaga kepercayaan nasabah dengan meningkatkan kualitas pelayanan agar kepuasan nasabahnya juga meningkat. Kondisi ini memunculkan pertanyaan yang mendasar mengenai bagaimana kepuasan nasabah bank Syariah serta faktor-faktor apa yang mampu memberikan pengaruh kepuasan terbesar untuk nasabah (Cahyani, 2016). Menjalin hubungan dan melakukan penelitian terhadap kepuasan nasabah perlu dilakukan agar kualitas pelayanan yang diberikan sesuai dengan yang diharapkan.
Sutanto dan Umam (2013) menjelaskan kepuasan nasabah adalah tingkat perasaan seseorang, setelah membandingkan kinerja produk atau jasa yang ia rasakan dengan harapannya. Harapan nasabah dibentuk oleh pengalaman nasabah terdahulu, komentar teman, rekomendasi teman, informasi dan janji dari bank dan pesaingnya melalui media promosi. Salah satu metode memantau dan mengukur kepuasan nasabah adalah dengan survei kepuasan. Lebih lanjut Mandal dan Bhattacharya (2013) mengemukakan pengukuran kepuasan nasabah ini terkait ekspektasi saat melakukan pembelian atau menerima pelayanan dari bank maupun reaksi nasabah setelah itu. Jika apa yang didapatkan nasabah sesuai atau melebihi apa yang diharapkan maka nasabah merasa puas, tetapi jika dibawah harapan maka nasabah tidak puas. Kepuasan nasabah berhubungan dengan sikap dan konsekuensi setelahnya, dan dalam penelitian ini konsekuensi tersebut adalah perilaku setelah pembelian (post purchase behavior). Berdasarkan penjelasan ini maka menilai hubungan antara kepuasan nasabah dan post purchase behavior penting untuk dilakukan.

Post purchase behavior yang dimaksud dalam penelitian ini yaitu perilaku yang dilakukan oleh konsumen pasca pembelian produk (dalam hal ini pelayanan bank syariah) sebagaimana didefinisikan oleh Engel et al. dalam Sangadji dan Sopiah (2013) bahwa perilaku konsumen sebagai tindakan yang langsung terlibat dalam pemerolehan, pengonsumsian dan penghabisan produk atau jasa, termasuk proses keputusan yang mendahului dan menyusuli tindakan ini. Sementara itu, Zeithaml et al. (1996) membagi intensitas perilaku konsumen ke dalam dua kelompok, yaitu perilaku menyukai dan perilaku tidak menyukai. Perilaku menyukai konsumen seperti mengatakan hal-hal positif, merekomendasikan perusahaan, tetap loyal dengan perusahaan, berbisnis lebih banyak dengan perusahaan, dan membayar dengan harga premium. Sedangkan perilaku tidak menyukai seperti mengatakan hal-hal yang negatif, pindah ke perusahaan lain, mengeluh kepada agen eksternal, dan melakukan bisnis lebih sedikit dengan perusahaan. Perilaku pasca pembelian ini dikelompokkan kedalam lima dimensi yaitu loyalitas, membayar lebih, pindah, respon eksternal dan respon internal. Variabel post purchase behavior dalam penelitian ini mengambil empat dimensi yang ada kecuali respon internal. 
Estiri et al. (2011) mereview serangkaian atribut yang dapat mengukur kepuasan nasabah di bank Islam. Selanjutnya, atribut ini dikelompokkan ke dalam dimensi kualitas pelayanan dengan metodologi Confirmatory Factor Analysis dan menguji validitas dan realibilitasnya. Hasil dari penelitian ini menunjukkan kepuasan nasabah dalam bank retail Islam (bank Syariah) bergantung pada dua faktor utama, yakni kualitas nilai dan kualitas pelayanan. Lima atribut atau dimensi kualitas pelayanan atau dikenal dengan SERVQUAL pertama kali diperkenalkan oleh Parasuraman et al. (1988) yang meliputi keberwujudan (tangible), keandalan (reliability), ketanggapan (responsiveness), keyakinan (assurance), dan empati (empathy). Satu dimensi lagi yang ditambahkan kepada perusahaan bernuansa syariah yaitu dimensi kepatuhan (compliance) dalam prinsip Islam sebagaimana diperkenalkan oleh Othman dan Owen (2001).

Penelitian tentang kualitas pelayanan dan kepuasan nasabah di bank syariah telah banyak dilakukan di berbagai negara. Khusus untuk penelitian SERVQUAl (lima dimensi kualitas pelayanan) yang kemudian ditambahkan satu dimensi Compliance pada institusi Syariah sebagaimana dikembangkan oleh Othman dan Owen (2001), yang kemudian dikenal dengan istilah model CARTER (Compliance, Assurance, Reliability, Tangible, Empathy, Responsiveness) pernah dilakukan di Malaysia (Abedniya dan Zaeim, 2011). Sementara untuk di Indonesia penelitian model CARTER telah dilakukan oleh Cahyani (2016). Dimensi kualitas pelayanan sebagai instrumen untuk mengukur kepuasan nasabah dalam penelitian ini juga menggunakan model CARTER.

Kualitas pelayanan yang diberikan bank syariah seharusnya telah dirasakan sepenuhnya oleh nasabahnya, kenyataanya masih ada masalah berupa keluhan nasabah mengenai kecepatan pelayanan dan kelengkapan fasilitas yang ada, yang disampaikan melalui kotak aduan. Keadaan ini bisa mempengaruhi kepuasan nasabahnya dan harus segera diantisipasi sebab kepuasan nasabah akan suatu pelayanan yang diberikan memberikan dampak tersendiri kepada perilaku post purchase behavior. Nasabah yang merasa puas akan berperilaku setia atau loyal sebagaimana hasil penelitian yang dilakukan oleh Junaedi (2012), Hastuti dan Nasri (2014), Ahmed et al. (2016) dan Atmaja (2018). Semakin tingi loyalitas konsumen terhadap suatu produk, semakin sulit bagi konsumen tersebut untuk pindah ke produk yang lain (Rahardjo et al. 2018). Tentunya hal ini berpengaruh positif bagi kelangsungan hidup bank syariah karena bersifat menguntungkan.

Sebaliknya nasabah yang merasa tidak puas dapat berperilaku pindah ke kompetitor atau melakukan komplain. Perilaku ini bepengaruh negatif bagi pihak bank karena sangat merugikan. Pihak bank juga dituntut bagaimana dalam mengahadapi komplain atau keluhan yang dilakukan nasabah, maka bank harus dapat cepat dan tepat dalam melakukan penanganan keluhan, supaya nasabah bisa merasakan kepuasan atas pelayanan penanganan keluhan yang dirasakan, sehingga nasabah bisa menjadi loyal terhadap bank tersebut (Arifin dalam Budiarti, 2010).

Peneltian yang mendekati sebelumnya adalah penelitian yang dilakukan oleh Zeithaml et al. (1996) yang berjudul "The Behavioral Consequences of Service Quality" yang menguji pengaruh kualitas pelayanan terhadap perilaku nasabah apakah tetap bertahan atau meninggalkan perusahaan. Hasil penelitian tersebut menunjukkan dari kelima dimensi perilaku pelanggan, loyalitas dan membayar lebih menunjukkan adanya konsisitensi pengaruh yang tinggi terhadap perusahaan pemberi jasa. Sementara pindah dan respon eksternal menunjukkan tingkatan konsistensi pengaruh moderat kearah tinggi. Dimensi terakhir, respon internal cukup berpengaruh. Pengaruh kepuasan nasabah terhadap loyalitas nasabah telah jamak dilakukan dengan berbagai metode penelitian baik yang kuantitaif maupun kualitatif. Sementara penelitian yang mengkhususkan hubungan antara kepuasan nasabah dengan post purchase behavior belum diteliti secara spesifik.

Berdasarkan latar belakang masalah yang telah diuraikan sebelumnya maka dari penelitian ini akan terjawab beberapa pertanyaan penelitian. Pertama, bagaimana tingkat kepuasan nasabah bank Syariah terhadap kualitas pelayanan yang diberikan oleh BSM Kantor Cabang Depok. Kedua, bagaimana rata-rata perilaku post purchase behavior nasabah bank Syariah dan yang ketiga, bagaimana hubungan antara kepuasan nasabah dengan post purchase behavior. Untuk menjawab pertanyaan penelitian ini dilakukan uji statistik baik deskriptif maupun uji tingkat kecenderungan hubungan atau uji Chi Square.

Penelitian ini bertujuan menganalisis hubungan antara kepuasan nasabah khususnya yang ada di BSM Kantor Cabang Depok dengan post purchase behaviour. 
Variabel dimensi kepuasan nasabah yang diteliti berdasarkan model CARTER yang diperkenalkan oleh Othman dan Owen (2001) sedangkan variabel Post Purchase Behaviour yang diteliti adalah hasil pengembangan dari studi Zeithaml (1996). Dengan mengetahui hubungan antara kepuasan nasabah dan post purchase behavior, bank syariah dapat melakukan strategi-strategi marketing serta komunikasi disamping perbaikan kualitas pelayanan yang pada akhirnya bank syariah dapat merumuskan langkah-langkah peningkatan dalam kualitas pelayanan ke depan.

\section{METODE PENELITIAN}

Penelitian ini dilakukan di Bank Syariah Mandiri(BSM) Kantor Cabang Depok. Lokasi penelitian beralamat di Ruko Depok Mas Blok A1-2 Jl. Margonda Raya No.42, Depok. Sedangkan waktu penelitian dilakukan mulai tanggal 29 November hingga 4 Desember 2017. Jenis data yang digunakan terdiri dari data ordinal dan data nominal atau data kategori. Data ordinal berupa peringkat dari kepuasan nasabah dan post purchase behavior dalam bentuk skala Likert yang dijumlah skornya. Sedangkan jenis data nominal digunakan untuk mengklasifikasikan data-data dianalisis dengan uji Chi Square $\left(\chi^{2}\right)$ dan tabulasi silang. Sumber data adalah data primer yang diperoleh langsung dari objek penelitian yaitu nasabah BSM melalui kuesioner dan wawancara.

Teknik atau metode pengambilan sampel yang dipakai menggunakan Non Probabilitas Sampling sementara jenis pengambilan sampelnya adalah purposive sampling. Dalam hal ini yang diminta menjadi responden adalah mereka yang telah menjadi nasabah di BSM Kantor Cabang Depok selama setahun atau lebih. Jumlah sampel dalam penelitian ini sebanyak 100 orang. Ada dua variabel yang diteliti, yakni variabel kepuasan nasabah dan variabel post purchase behavior. Untuk variabel kepuasan nasabah yang diadopsi dari penelitian Othman dan Owen (2001) dapat dilihat pada Tabel 2. Selanjutnya, untuk variabel post purchase behavior yang diadopsi dari penelitian Zeithaml et al. (1996) dapat dilihat pada Tabel 3.

\begin{tabular}{ll}
\hline Dimensi & Sub variabel \\
\hline $\begin{array}{l}\text { Keberwujudan } \\
\text { (Tangible) }\end{array}$ & $\begin{array}{l}\text { Peralatan dan teknologi canggih } \\
\text { operasional bank }\end{array}$ \\
& Keberadaan ATM 24 jam on-line \\
& Keberadaan tempat parkir yang \\
cukup luas dan aman & Penataan eksterior dan interior kantor \\
& yang baik \\
& Kebersihan toilet \\
& Memberikan perhatian individu \\
kepada nasabah & Bertanggung jawab atas privasi \\
nasabah & Kepekaan karyawan terhadap privasi \\
(Empathy) & nasabah \\
& $\begin{array}{l}\text { Kepekaan karyawan terhadap } \\
\text { kebutuhan nasabah }\end{array}$ \\
& $\begin{array}{l}\text { Pelayanan sepenuh hati kepada setiap } \\
\text { nasabah }\end{array}$ \\
& Kemampuan bank menghadapi \\
masalah yang timbul
\end{tabular}

Kemampuan karyawan bekomunikasi dengan nasabah

Kemampuan bank tanggap terhadap keluhan nasabah

Ketanggapan karyawan dalam operasional bank

Kecepatan karyawan melayani transaksi nasabah. 
Teknik analisis data hubungan kepuasan nasabah bank syariah dengan post purchase behavior digunakan uji Chi Square $\left(\chi^{2}\right)$. Uji ini untuk menguji signifikansi hipotesis komparatif dua atau lebih sampel independen bila datanya berbentuk nominal. Untuk mengetahui perhitungan nilai Chi Square secara cepat dapat digunakan prosedur deskriptif-cross tab pada paket program SPSS for Windows Versi.24. Kriteria penilaiannya yaitu jika besar nilai pearson Chi Square hitung lebih besar dari nilai Chi Square tabel maka tolak Ho, atau dengan melihat signifikansinya, jika lebih besar dari 0,05 maka tolak Ho. Untuk mengetahui kecenderungan hubungan diantara keduanya dilihat dari koefisien kontingensinya (Sugiyono, 2015) dimana besar interval koefisien dan interpretasinya dapat dilihat pada Tabel 4.

Berdasarkan tujuan penelitian, kajian teoritis dan empiris yang ada maka hipotesis dari penelitian ini adalah sebagai berikut: Ho : Tidak ada hubungan antara kepuasan nasabah dengan post purchase behavior; $\mathrm{H} 1$ : ada hubungan antara kepuasan nasabah dengan post purchase behavior.
Kerangka pemikiran dari penelitian ini adalah kepuasan nasabah bank syariah memiliki hubungan dengan perilaku post purchase behaviornya. Dimana dalam hal ini nasabah yang memberi nilai positif atau tinggi dan merasa puas terhadap bank syariah akan semakin berminat untuk menggunakan atau memilih kembali jasa bank syariah tesebut atau berperilaku loyalitas dan bersedia bayar lebih. Sebaliknya, bila nasabah memberi penilaian negatif atau rendah dan merasa tidak puas atas pelayanan suatu bank syariah, maka ia akan melakukan perilaku pindah dan atau respon eksternal. Gambaran lengkap kerangka pemikiran hubungan kepuasan nasabah dan post purchase behavior nasabah bank syariah pada Gambar 1 .

\section{HASIL}

\section{Analisis Deskripsi Kepuasan Nasabah}

Hasil analisis deskriptif dari variabel kepuasan nasabah, yakni kepatuhan, keyaknian, keandalan, keberwujudan, empati dan ketanggapan dapat dilihat pada Tabel 5. Penilaian terhadap variabel kepuasan nasabah dikelompokkan menjadi 5 kategori mulai dari sangat tidak puas hingga sangat puas. Berikut frekuensi hasil penilaian untuk setiap kategori.

Tabel 3. Variabel post purchase behavior

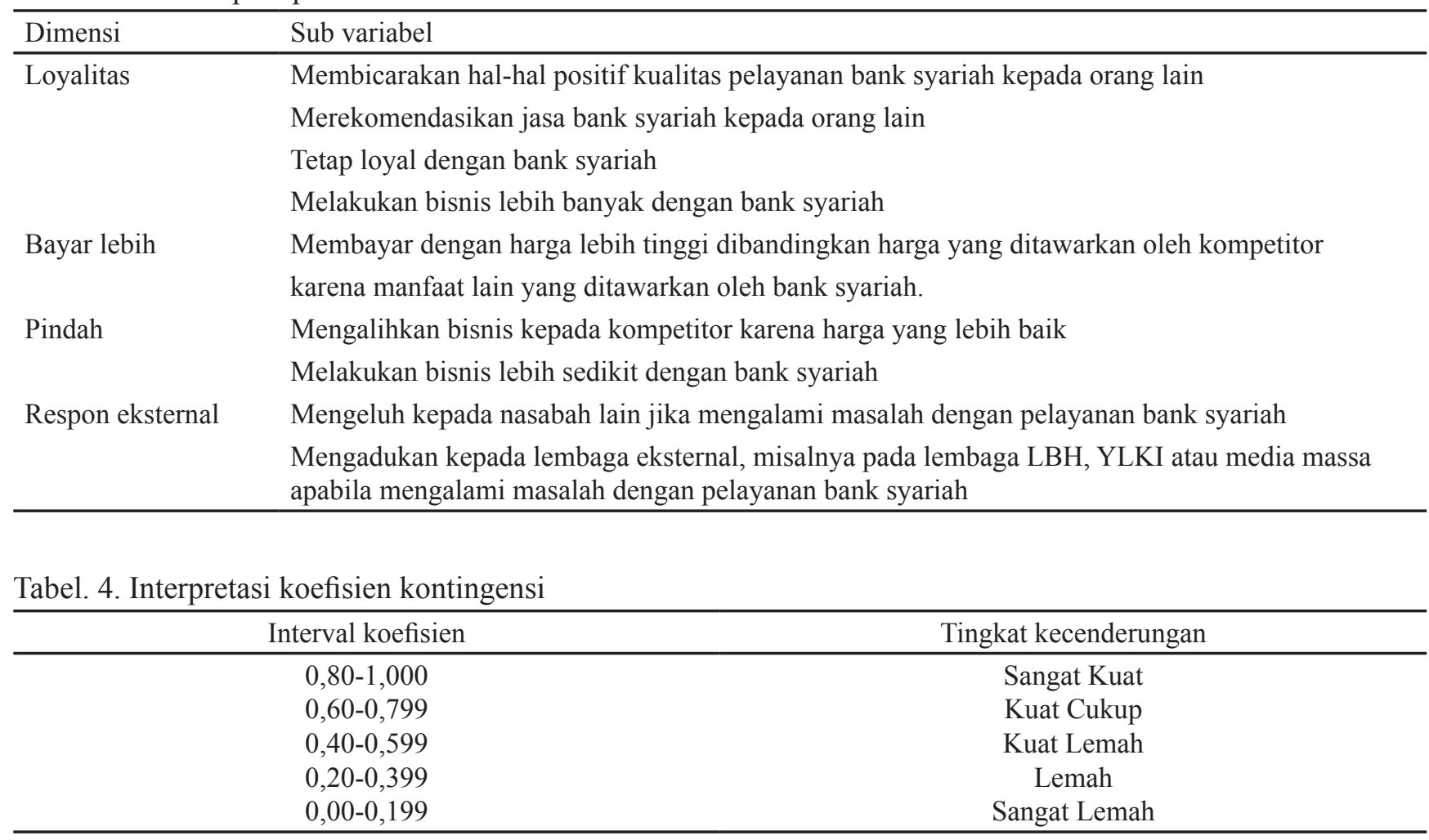






Gambar 1. Kerangka pemikiran

Tabel 5. Hasil analisis deskriptif kepuasan nasabah

\begin{tabular}{|c|c|c|c|c|c|c|c|c|c|}
\hline \multirow{2}{*}{ Subvariabel } & \multicolumn{5}{|c|}{ Frekuensi } & \multirow{2}{*}{ Rata-rata } & \multirow{2}{*}{ Min } & \multirow{2}{*}{ Maks } & \multirow{2}{*}{ Std, Dev } \\
\hline & 1 & 2 & 3 & 4 & 5 & & & & \\
\hline Kepatuhan1 & 0 & 2 & 9 & 68 & 21 & 4,08 & 2 & 5 & 0,6143 \\
\hline Kepatuhan2 & 0 & 10 & 17 & 52 & 21 & 3,84 & 2 & 5 & 0,8729 \\
\hline Kepatuhan3 & 0 & 2 & 20 & 60 & 18 & 3,94 & 2 & 5 & 0,679 \\
\hline Kepatuhan4 & 0 & 0 & 9 & 64 & 27 & 4,18 & 3 & 5 & 0,5752 \\
\hline Kepatuhan5 & 0 & 3 & 17 & 57 & 23 & 4,01 & 2 & 5 & 0,7316 \\
\hline Keyakinan 1 & 0 & 2 & 6 & 61 & 31 & 4,21 & 2 & 5 & 0,6403 \\
\hline Keyakinan 2 & 0 & 1 & 6 & 61 & 32 & 4,24 & 2 & 5 & 0,605 \\
\hline Keyakinan 3 & 0 & 2 & 22 & 60 & 16 & 3,9 & 2 & 5 & 0,6742 \\
\hline Keyakinan 4 & 0 & 0 & 19 & 62 & 19 & 4 & 3 & 5 & 0,6195 \\
\hline Keyakinan 5 & 0 & 1 & 17 & 71 & 11 & 3,92 & 2 & 5 & 0,5628 \\
\hline Keandalan 1 & 1 & 1 & 37 & 47 & 14 & 3,9 & 2 & 5 & 0,6742 \\
\hline Keandalan 2 & 2 & 8 & 22 & 51 & 17 & 3,73 & 1 & 5 & 0,9085 \\
\hline Keandalan 3 & 0 & 0 & 13 & 71 & 16 & 4,03 & 3 & 5 & 0,5404 \\
\hline Keandalan 4 & 1 & 2 & 11 & 68 & 18 & 4 & 1 & 5 & 0,6816 \\
\hline Keandalan 5 & 0 & 0 & 24 & 59 & 17 & 3,93 & 3 & 5 & 0,6397 \\
\hline Keberwujudan 1 & 0 & 8 & 19 & 53 & 20 & 3,85 & 2 & 5 & 0,8333 \\
\hline Keberwujudan 2 & 2 & 4 & 22 & 44 & 28 & 3,92 & 1 & 5 & 0,9176 \\
\hline Keberwujudan 3 & 1 & 14 & 30 & 46 & 9 & 3,48 & 1 & 5 & 0,8817 \\
\hline Keberwujudan 4 & 0 & 1 & 26 & 58 & 15 & 3,87 & 2 & 5 & 0,6614 \\
\hline Keberwujudan 5 & 1 & 1 & 37 & 47 & 14 & 3,72 & 1 & 5 & 0,7532 \\
\hline Empati1 & 1 & 3 & 30 & 56 & 10 & 3,71 & 1 & 5 & 0,7288 \\
\hline Empati2 & 0 & 0 & 11 & 72 & 17 & 4,06 & 3 & 5 & 0,5284 \\
\hline Empati3 & 0 & 1 & 29 & 63 & 7 & 3,76 & 2 & 5 & 0,5881 \\
\hline Empati4 & 0 & 3 & 30 & 59 & 8 & 3,72 & 2 & 5 & 0,6526 \\
\hline Empati5 & 0 & 3 & 30 & 52 & 15 & 3,79 & 2 & 5 & 0,7288 \\
\hline Ketanggapan1 & 0 & 2 & 48 & 46 & 4 & 3,52 & 2 & 5 & 0,611 \\
\hline Ketanggapan 2 & 0 & 2 & 12 & 68 & 18 & 4,01 & 2 & 5 & 0,6276 \\
\hline Ketanggapan 3 & 0 & 4 & 27 & 60 & 9 & 3,74 & 2 & 5 & 0,676 \\
\hline Ketanggapan 4 & 0 & 3 & 26 & 60 & 11 & 3,79 & 2 & 5 & 0,6711 \\
\hline Ketanggapan 5 & 2 & 3 & 18 & 63 & 14 & 3,84 & 1 & 5 & 0,7749 \\
\hline Kepuasan Total & 1 & 0 & 18 & 60 & 21 & 4 & 1 & 5 & 0,6963 \\
\hline
\end{tabular}

Keterangan : $1=$ Sangat tidak puas $2=$ tidak puas $3=$ netral $4=$ puas $5=$ sangat puas 
Dari data diatas terlihat bahwa rata-rata jawaban responden lebih dari nilai 3 (tiga) dari 5 (lima) skala. Dapat ditafsirkan rata-rata responden mempunyai tingkat kepuasan yang tinggi terhadap kualitas pelayanan yang diberikan. Sub variabel yang memiliki nilai rata-rata tertinggi adalah Keyakinan 2, yaitu berupa kesopanan karyawan dalam melayani nasabah (Rata-rata $=4,24)$. Hal ini sejalan dengan penelitian yang dilakukan oleh Cahyani (2016) tentang tingkat kepuasan nasabah bank Syariah di Yogyakarta.

Wajar jika responden memberi nilai tinggi atas variabel ini. Secara nyata pegawai BSM Kantor Cabang Depok telah menunjukkan kesopanan kepada nasabah. Mulai dari saat nasabah masuk disambut dengan senyum dan disapa dengan "Assalamu'alaikum, ada yang bisa kami bantu?" hingga akhir transaksi nasabah dilayani dengan sopan dan ramah. Nilai rata-rata dari subvariabel Keyakinan 1, yaitu keramahan karyawan dalam melayani nasabah juga tinggi (Rata-rata $=4,21$ ).

Dalam suasana kerja terutama yang berhubungan dengan pelayanan terhadap orang lain, kesopanan dan keramahan para pegawai sangat dihargai oleh konsumen. Terkait dengan hal ini Islam mengajarkan suatu budaya atau sikap yang sangat baik untuk dibiasakan yaitu sikap tabassun (tersenyum). Senyum merupakan sesuatu yang kurang pada diri manusia saat ini. Jika seorang pegawai bank memiliki wajah yang selalu cemberut dan menunjukkan wajah yang banyak masalah, hal itu akan memberi penilaian buruk dari nasabah. Rasululloh SAW menyebutkan dalam hadist beliau: "Senyummu itu kepada saudaramu bagimu adalah merupakan sedekahmu" (Hadist Riwayat Bukhori dan Muslim). Dengan tersenyum ternyata akan melahirkan cinta, kasih sayang dan orang lain akan merasa dihargai (Hafiduddin dan Tanjung, 2006).

\section{Deskripsi Post purchase behavior}

Rata-rata perilaku post purchase behavior responden bernilai diatas 3 untuk loyalitas dan bayar lebih. Hal ini bisa dinterpretasikan responden mempunyai nilai persetujuan untuk tetap loyal dan bersedia membayar lebih bila BSM Kantor Cabang Depok meningkatkan harga yang ditawarkan oleh karena ada manfaat lain yang ditawarkannya. Sedangkan untuk perilaku pindah dan respon eksternal, rata-ratanya bernilai 2. Hal ini bisa dijelaskan bahwa responden hampir tidak setuju untuk pindah ke bank lain atau melakukan pengaduan kepada pihak ketiga walaupun mengalami masalah dengan bank syariah. Hasil Analisis Deskriptif Post purchase behavior Lebih lengkapnya pada Tabel 6 .

\section{Hubungan Kepuasan Nasabah dengan Post purchase behavior}

Tabel 7 menunjukkan hubungan kepuasan nasabah dengan post purchase behavior di BSM Depok. Terdapat hubungan yang cukup kuat antara kepuasan nasabah dengan post purchase behaviour Loyalitas 1, Loyalitas 2, Loyalitas 3 dan loyalitas 4, pindah 1, Respon Eksternal 1 dan Respon Eksternal 2. Hal ini bisa dilihat dari uji nilai koefisien kontingensi $C h i$ Square yang signifikan. Jika nilai koefisien kontingensi antara 0,4-0,599. Artinya, kecenderungannya cukup kuat. Bisa dikatakan semakin puas nasabah dengan kualitas pelayanan yang diberikan bank syariah maka cenderung untuk setuju untuk berperilaku loyal. Sebaliknya apabila terdapat ketidakpuasan nasabah terhadap bank syariah ada kecendurangan kuat untuk pindah ke bank yang lain maupun melakukan respon eksternal.

Kepuasan dan ketidakpuasan pelanggan akan suatu produk (jasa) sebagai akhir dari suatu proses penjualan memberikan dampak tersendiri kepada perilaku pelanggan terhadap produk tersebut. Diantaranya bagaimana perilaku pelanggan dalam melakukan pembelian kembali, mengekspresikan pelayanan yang diperolehnya, serta perilaku lain yang menggambarkan reaksi pelanggan atas pelayanan yang telah dirasakan. pelanggan yang menikmati produk (jasa) mungkin akan mengembangkan sikap yang mendukung perusahaan penghasil produk (jasa) tersebut, misalnya dengan berkata positif tentang produk,merekomendasikan perusahaan terkait kepada orang lain, loyal kepada produk perusahaan, dan membayar produk dengan harga premium. Sebaliknya, produk yang gagal bekerja sebagaimana yang diharapkan dapat dengan mudah menimbulkan sikap negatif, misalnya dengan berkata negatif tentang produk, pindah ke perusahaan lain, tidak memiliki bisnis yang banyak dengan perusahaan, bahkan mengajukan tuntutan terhadap perusahaan melalui agensi luar (Lupiyoadi dan Hamdani, 2006). 
Tabel 6. Hasil analisis deskriptif post purchase behavior

\begin{tabular}{|c|c|c|c|c|c|c|c|c|c|}
\hline \multirow{2}{*}{ Subvariabel } & \multicolumn{5}{|c|}{ Frekuensi } & \multirow{2}{*}{ Rata-rata } & \multirow{2}{*}{ Min } & \multirow{2}{*}{ Maks } & \multirow{2}{*}{ Std. Dev } \\
\hline & 1 & 2 & 3 & 4 & 5 & & & & \\
\hline Loyalitas1 & 0 & 4 & 27 & 54 & 15 & 3,8 & 2 & 5 & 0,7385 \\
\hline Loyalitas2 & 0 & 3 & 32 & 50 & 15 & 3,77 & 2 & 5 & 0,7366 \\
\hline Loyalitas3 & 0 & 2 & 31 & 54 & 13 & 3,78 & 2 & 5 & 0,6902 \\
\hline Loyalitas4 & 0 & 4 & 42 & 47 & 7 & 3,57 & 2 & 5 & 0,6854 \\
\hline Bayar Lebih & 2 & 9 & 61 & 24 & 4 & 3,19 & 1 & 5 & 0,7344 \\
\hline Pindah1 & 10 & 39 & 41 & 9 & 1 & 2,52 & 1 & 5 & 0,8346 \\
\hline Pindah2 & 4 & 26 & 56 & 11 & 3 & 2,83 & 1 & 5 & 0,7921 \\
\hline Respon Eksternal1 & 8 & 26 & 42 & 18 & 6 & 2,88 & 1 & 5 & 0,9978 \\
\hline Respon Eksternal2 & 8 & 30 & 37 & 19 & 6 & 2,85 & 1 & 5 & 1,0118 \\
\hline
\end{tabular}

Keterangan : $1=$ Sangat tidak puas $2=\operatorname{tidak}$ puas $3=$ netral $4=$ puas $5=$ sangat puas

Tabel 7. Tingkat kecenderungan hubungan kepuasan nasabah dengan post purchase behavior

\begin{tabular}{|c|c|c|c|c|c|}
\hline \multirow[b]{2}{*}{ Post Purchase Behaviour } & \multicolumn{3}{|c|}{ Pearson Chi-Square } & \multirow{2}{*}{$\begin{array}{c}\text { Contingency } \\
\text { Coefficient }\end{array}$} & \multirow{2}{*}{$\begin{array}{c}\text { Tingkat } \\
\text { Kecenderungan }\end{array}$} \\
\hline & Value & $d f$ & $\begin{array}{l}\text { Asymp, Sig, } \\
\text { (2-sided) }\end{array}$ & & \\
\hline $\begin{array}{l}\text { Loyalitas 1: Membicarakan Hal-hal Positif } \\
\text { Kualitas Pelayanan Bank Syariah Kepada Orang } \\
\text { Lain }\end{array}$ & 34,798 & 9 & 0,000 & 0,508 & Cukup Kuat \\
\hline $\begin{array}{l}\text { Loyalitas 2: Merekomendasikan jasa bank syariah } \\
\text { kepada orang lain }\end{array}$ & 20,144 & 9 & 0,017 & 0,409 & Cukup Kuat \\
\hline Loyalitas 3: Tetap loyal dengan bank syariah & 23,640 & 9 & 0,005 & 0,437 & Cukup Kuat \\
\hline $\begin{array}{l}\text { Loyalitas } 4 \text { : Melakukan bisnis lebih banyak } \\
\text { dengan bank syariah }\end{array}$ & 14,877 & 9 & 0,094 & 0,414 & Cukup Kuat \\
\hline $\begin{array}{l}\text { Membayar dengan harga lebih tinggi } \\
\text { dibandingkan harga yang ditawarkan oleh } \\
\text { kompetitor }\end{array}$ & 8,843 & 12 & 0,716 & 0,285 & Lemah \\
\hline $\begin{array}{l}\text { Pindah } 1 \text { : Mengalihkan bisnis kepada kompetitor } \\
\text { karena harga yang lebih baik }\end{array}$ & 27,572 & 12 & 0,006 & 0,465 & Cukup Kuat \\
\hline $\begin{array}{l}\text { Pindah } 2 \text { : Melakukan bisnis lebih sedikit dengan } \\
\text { bank syariah }\end{array}$ & 14.220 & 12 & $0,, 87$ & 0,353 & Lemah \\
\hline $\begin{array}{l}\text { Respon Eksternal } 1: \text { Mengeluh kepada nasabah } \\
\text { lain jika mengalami masalah dengan pelayanan } \\
\text { bank syariah }\end{array}$ & 35,027 & 12 & 0,000 & 0,509 & Cukup Kuat \\
\hline $\begin{array}{l}\text { Respon Eksternal } 2 \text { : Mengadukan kepada } \\
\text { lembaga eksternal, misalnya pada lembaga LBH, } \\
\text { YLKI atau media massa apabila mengalami } \\
\text { masalah dengan pelayanan bank syariah }\end{array}$ & 28,542 & 12 & 0,005 & 0,471 & Cukup Kuat \\
\hline
\end{tabular}

Keterangan : $1=$ Sangat tidak puas $2=$ tidak puas $3=$ netral $4=$ puas $5=$ sangat puas

Berdasarkan data pada Tabel 7 dapat ditarik satu hal bahwa kepuasan nasabah yang tingi erat hubungannya dengan perilaku nasabah untuk menceritakan atau memberikan informasi baik positif maupun negatif kepada orang lain. Hal ini bisa dilihat dari value Pearson Chi Square yang lebih tinggi pada perilaku Loyalitas 1 (membicarakan hal-hal positif kualitas pelayanan bank syariah kepada orang lain) dan Respon Eksternal 1 (mengeluh kepada nasabah lain jika mengalami masalah dengan pelayanan bank syariah). Dengan kata lain informasi dari mulut ke mulut nasabah ini (word of mouth/WOM) berperan sangat penting dalam mempromosikan jasa bank syariah. Bentuk komunikasi seperti ini sangat besar pengaruhnya dan dampaknya terhadap pemasaran bank dibandingkan dengan aktivitas komunikasi lainnya. Penelitian tentang kuatnya pengaruh WOM terhadap keputusan pembelian konsumen ini telah diuji oleh Joesyiana (2018). 
Signifikansi loyalitas pelanggan sangat erat terkait dengan kelangsungan perusahaan dan terhadap kuatnya pertumbuhan perusahaan di masa mendatang. Dengan mengetahui hubungan perilaku tetap loyal dengan bank syariah dengan kualitas pelayanan dan kepuasan nasabah dapat dirumuskan strategi untuk mempertahankan nasabah yang loyal. Nasabah yang merasa puas dengan kualitas pelayanan bank syariah semestinya akan semakin setuju untuk membayar dengan harga lebih tinggi dibandingkan harga yang ditawarkan oleh kompetitor. Hal ini tidak terbukti dalam penelitian ini (Tabel 7). Hubungan kepuasan nasabah dengan perilaku ini lemah, nilai signifikansi uji Chi Square 0,716 tidak lebih kecil dari 0,05. Artinya, kepuasan nasabah tidak berhubungan signifikan dengan perilaku membayar harga yang yang lebih tinggi yang ditawarkan oleh kompetitor.

Fenomena adanya beberapa nasabah walaupun merasa sangat puas, namun tidak setuju untuk bersedia membayar lebih ini dikarenakan nasabah merasa rugi untuk membayar tambahan dan berpikir kembali apabila harus membayar dengan harga lebih tinggi dibandingkan harga yang ditawarkan oleh kompetitor. Hal ini menjelaskan bahwa nasabah bank Syariah masih bersifat rasional. Artinya, faktor harga masih berpengaruh besar bagi mereka dalam mengambil keputusan. Hasil penelitian ini tidak sejalan dengan hasil penelitian Cronin dan Taylor (1992). Penelitian Cronin dan Taylor menyimpulkan adanya pengaruh yang signifikan antara kepuasan konsumen dengan perilaku untuk membayar lebih. Hal ini disebabkan adanya perbedaan metode analisis yang digunakan, Cronin menggunakan analisis dengan LISREL, sedangkan penelitian ini dengan Chi Square.

Di dalam suatu proses keputusan, konsumen tidak akan berhenti hanya sampai proses konsumsi. Konsumen akan melakukan proses evaluasi terhadap konsumsi yang telah dilakukannya. Inilah yang disebut sebagai evaluasi alternatif pasca pembelian atau pasca konsumsi. Proses ini bisa juga disebut sebagai proses evaluasi alternatif tahap kedua. Hasil dari proses evaluasi pasca konsumsi adalah konsumen puas atau tidak puas terhadap konsumsi produk atau merek yang telah dilakukannya. Setelah mengkonsumsi suatu produk atau jasa, konsumen akan memiliki perasaan puas atau tidak puas terhadap produk atau jasa yang dikonsumsinya. Kepuasan akan mendorong konsumen membeli dan mengkonsumsi ulang produk tersebut. Sebaliknya perasaan yang tidak puas akan menyebabkan konsumen kecewa dan menghentikan pembelian kembali produk tersebut (Sumarwan, 2015).

Konsumen yang kecewa atau tidak puas akan melakukan bisnis yang lebih sedikit atau mengurangi interaksi dengan produk tersebut. Dari hasil penelitian ini hubungan ketidakpuasan nasabah dengan post purchase behavior perilaku pindah 2 kecenderungannya lemah (nilai koefisien kontingensi 0,353). Artinya, nasabah BSM kantor cabang depok walaupun merasa tidak puas dengan pelayanan yang diberikan oleh bank belum tentu melakukan bisnis yang lebih sedikit dengan bank tersebut. Penjelasan akan hal ini adalah karena tingkat loyalitas nasabah yang cukup kuat, yakni nilai ratarata $>3$ (Tabel 6) artinya nasabah akan tetap berbisnis dengan bank syariah walalupun tidak puas atau melakukan perilaku yang lebih ekstrim yakni pindah ke kompettitor lain dengan harga yang lebih baik. Hubungan antara kepuasan nasabah dengan perilaku pindah ini cukup kuat (nilai koefisien kontigensi 0,465). Penyebab lainnya adalah karena tingginya tingkat kepercayaan nasabah kepada bank Syariah, hal ini disebabkan konsep amanah yang sangat melekat pada setiap transaksi di institusi keuangan Islam (Ali, 2017), termasuk bank Syariah.

\section{Implikasi Manjerial}

Kendati secara umum nasabah telah menilai puas atas kualitas pelayanan yang diberikan BSM Kantor Cabang Depok, disarankan kepada pihak bank untuk terus meningkatkan kualitas pelayanannya serta merangkul nasabah yang tidak merasa puas dengan memperhatikan lebih serius dalam beberapa hal. Pertama meningkatkan kecepatan pelayanan yang diberikan dengan cara menambah personel di bagian depan, yaitu teller dan customer service dan atau dengan meningkatkan keahlian dan keterampilan personelnya sehingga tidak akan ditemukan lagi keluhan akan pelayanan yang antriannya panjang dan membosankan. Kedua meningkatkan kualitas pelayanan dalam dimensi keberwujudan seperti memperbanyak ATM BSM 24 jam on-line, memperluas tempat parkir dan memberikan keamanan pada nasabah yang melakukan transaksi serta menyediakan sarana ibadah dan umum (toilet) di tempat yang mudah dijangkau. Ketiga memperkuat brand dan citra BSM, sejalan dengan visinya sebagai bank terpercaya yang diselaraskan dengan aplikasinya dalam memberikan pelayanan terhadap nasabah dalam 
bentuk ramah dan sopan dalam menjalani nasabah, jujur dan kepastian dalam setiap transaksi serta meningkatkan pengetahuan karyawan dalam produkproduk yang ditawarkan.

\section{KESIMPULAN DAN SARAN}

\section{Kesimpulan}

Secara umum, sebagian besar nasabah menyatakan kepuasan yang cukup tinggi pada setiap dimensi kualitas pelayanan yang diberikan. Hal ini dapat disebabkan BSM Kantor Cabang Depok telah menerapkan budaya kerja yang berstandard untuk pelayan yang harus diberikan. Meskipun demikian, kenyataan adanya nasabah yang tidak puas dan bersedia untuk pindah ke bank lain merupakan peringatan bagi BSM untuk segera mengambil langkah-langkah yang tepat agar tidak berdampak buruk bagi nasabah lainnya.

Rata-rata perilaku post purchase behavior responden menyatakan hampir setuju untuk loyalitas dan bayar lebih. Sedangkan untuk perilaku pindah dan respon eksternal, rata-rata responden hampir tidak setuju untuk pindah ke bank lain atau melakukan pengaduan kepada pihak ketiga walaupun mengalami masalah dengan bank syariah. Hal ini menunjukkan responden memberikan nilai postif kepada bank syariah

Terdapat kecenderungan hubungan yang cukup kuat antarakepuasannasabah dengan post purchasebehavior. Perilaku tersebut adalah empat bentuk loyalitas seperti membicarakan hal-hal positif kualitas pelayanan bank syariah kepada orang lain, merekomendasikan jasa bank syariah kepada orang lain, tetap loyal dengan bank syariah dan melakukan bisnis lebih banyak dengan bank syariah. Perilaku lainnya yang memiliki hubungan cukup kuat dengan kepuasan nasabah yakni pindah dalam bentuk mengalihkan bisnis kepada kompetitor karena harga yang lebih baik dan dua bentuk respon eksternal yakni mengeluh kepada nasabah lain dan mengeluh kepada pihak ketiga. Sementara itu, perilaku yang memiliki hubungan yang lemah dengan kepuasan nasabah yaitu membayar dengan harga lebih tinggi dibandingkan harga yang ditawarkan oleh kompetitor dan pindah dalam bentuk melakukan bisnis lebih sedikit dengan bank syariah

\section{Saran}

Bank Syariah hendaknya mentradisikan survei persepsi kepuasan nasabah terhadap seberapa baik kualitas pelayanan bank syariah dan hubungannya dengan post purchase behavior sehingga dapat dipantau kemajuan atas pencapaian hasil program-program atau kebijakan yang telah ditempuh dan dampaknya terhadap kepentingan nasabah. Penelitian selanjutnya disarankan mengambil sampel nasabah bank Syariah khusus pengguna mobile atau internet banking. Selain itu bank syariah tidak perlu menghambat nasabah yang akan pindah namun perlu menggali informasi untuk mengetahui alasan sebenarnya serta mengevaluasi kelebihan dan kekurangan bank-bank pesaing.

\section{DAFTAR PUSTAKA}

Abedniya A, Zaeim MN. 2011. Measuring the perceive service quality in Islamic banking system in Malaysia. International Journal of Business and Social Science 2(13): 122-135.

Ahmed SM, Khaliq A, Muhamad TJ. 2016. The impact of service quality on customer satisfaction and customer loyalty: An empirical study on Islamic banks in Bahrain. Al-Sharjah: Journal of Islamic Thought and Civilization of The International Islamic University Malaysia (ISTAC) 21(3): 261-282.

Ali SN. 2017. Building trust in Islamic finance products and services. Society and Business Review 12(3): 356-372. https://doi.org/10.1108/SBR-03-20170017.

Amin M. 2012. Bank-bank Syariah Dunia. https:// aminisme.wordpress.com/2012/01/16/bankbank-syariah-dunia [16 Januari 2012].

Atmaja J. 2018. Kualitas pelayanan dan kepuasan nasabah terhadap loyalitas pada bank BJB. Jurnal Ecodemica 2(1): 49-63. https://doi. org/10.24912/jmbk.v2i1.4812.

Budiarti A. 2010. Pengaruh kualitas layanan dan penanganan keluhan terhadap kepuasan dan loyalitas nasabah bank umum Syariah di Surabaya. Ekuitas 15(2): 210-231. https://doi. org/10.24034/j25485024.y2011.v15.i2.2289.

Cahyani PD. 2016. Tingkat kepuasan nasabah terhadap kualitas layanan perbankan syariah di Yogyakarta. Jurnal Bisnis dan Manajemen 6(2): 151-162. https://doi.org/10.15408/ess.v6i2.3570. 
Cronin JJ, Taylor AA. 1992. Measuring service quality: a reexamination and extension. Journal of Marketing 56(1): 55-68. https://doi. org/10.1177/002224299205600304.

Estiri M, Hosseini F, Yadzani H, Nejad HJ. 2011. Determinants of customer satisfaction in Islamic banking: evidence from Iran. International Journal of Islamic Middle Eastern Finance and Management 4(4): 295-307. https://doi. org/10.1108/17538391111186546.

Hafidhuddin D, Tanjung H, 2006. Shariah Principles On Management In Practice. Jakarta: Gema Insani.

Hastuti T, Nasri M. 2014. Kualitas pelayanan, kepuasan dan loyalitas nasabah: Aplikasi SERVQUAL model pada Lembaga keuangan mikro Syariah di kota Malang. Jurnal Manajemen dan Akuntansi 3(3): 73-93.

Joesiyana K. 2018. Pengaruh word of mouth terhadap keputusan pembelian konsumen pada media online shop shopee di pekanbaru (Survey pada Mahasiswa Semester VII Jurusan Pendidikan Akuntansi Fakultas Keguruan dan Ilmu Pendidikan Universitas Islam Riau). Jurnal Valuta 4(1): 71-85.

Junaedi AT. 2012. Analisis pengaruh kualitas pelayanan, keadilan dan kepuasan nasabah terhadap loyalitas nasabah bank Syariah (studi pada nasabah bank Syariah di propinsi Riau). Jurnal Aplikasi Manajemen 10(1): 161-176.

Lupiyoadi R, Hamdani A. 2006. Manajemen Pemasaran Jasa, Edisi Kedua. Jakarta: Salemba Empat.

MandalPC, Bhattacharya S. 2013. Customer satisfaction in Indian retail banking: A grounded theory approach. The Qualitative Report 18(56): 1-21. https://doi.org/10.1504/IJQRS.2013.056334.

[OJK] Otoritas Jasa Keuangan. 2018. Statistik Perbankan Syariah Juni 2018. https:/www. ojk.go.id/id/kanal/syariah/data-dan-statistik/ statistik-perbankansyariah/Pages/StatistikPerbankan-Syariah---Juni-2018.aspx. [1 Juni 2018].

[OJK] Otoritas Jasa Keuangan. 2008. Statistik Perbankan Syariah Juni 2008. https:/www. ojk.go.id/id/kanal/syariah/data-dan-statistik/ statistik-perbankan-syariah/Documents/ JUN22082008 1390376527.pdf. [1 Juni 2008].

Othman, Owen. 2001. Adopting and measuring customer Service Quality (SQ) in Islamic banks: A case study in Kuwait Finance House. International Journal of Islamic Financial Services 3(1): 1-26.

Parasuraman A, Zeithaml VA, Berry LL. 1988. Servqual: A multiple-item scale for measuring consumer perceptions of service quality. Journal of Retailing 64 (1): 14-40.

Rahardjo CR, Harianto, Suwarsinah HK. 2019. The effect of Marketing mix on customer satisfaction and loyalty for Indonesian brand salad dressing xyz. Jurnal Aplikasi Bisnis dan Manajemen (JABM) 5(2): 308-318.https://doi.org/10.17358/ jabm.5.2.308.

Sangadji EM, Sopiah. 2013. Perilaku Konsumen Pendekatan Praktis disertai Himpunan Jurnal Penelitian. Yoyakarta: CV. Andi Offset.

Sumarwan U. 2015. Perilaku Konsumen Teori dan Penerapannya Dalam Pemasaran. Bogor: Ghalia Indonesia.

Sugiyono. 2015. Statistik Nonparametris Untuk Penelitian. Bandung: Alfabeta.

Sutanto H, Umam K. 2013. Manajemen Pemasaran Bank Syariah. Bandung: CV Pustaka Setia.

Zeithaml VA, Berry LL, Parasuraman A. 1996. The behavior consequences of service quality. Journal of Marketing 60(4): 31-46. https://doi. org/10.2307/1251929. 